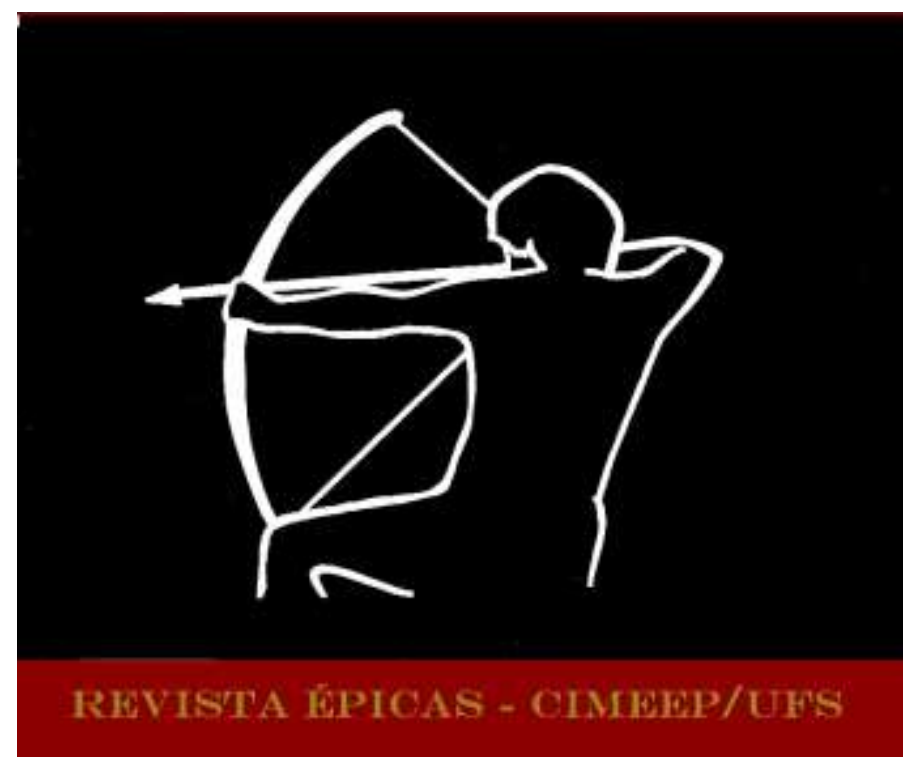

FELIPE, Cleber Vinicius do Amaral. A máquina do mundo e o heroísmo de Vasco da Gama. In: Revista Épicas. Ano 4, N. 7, Jun 2020, p. 1-18. ISSN 2527-080-X.

\title{
A MÁQUINA DO MUNDO E O HEROÍSMO DE VASCO DA GAMA
}

\author{
THE WORD'S MACHINE AND THE HEROISM OF VASCO DA GAMA
}

Cleber Vinicius do Amaral Felipe INHIS - UFU

RESUMO: não é novidade a esta altura dizer que Camões imitou a poesia greco-romana, especialmente as epopeias de Homero e Virgílio. No entanto, a conduta de Vasco da Gama nem sempre se ajusta às ações de Aquiles ou Odisseu, pois no século XVI há uma concepção providencialista de tempo, isto é, supõe-se a existência de um Deus único e onipresente que assiste aos desconcertos do mundo. Sendo assim, o presente artigo desdobra-se em três momentos. No primeiro, retoma-se um modelo de conduta nem sempre considerado pelos leitores que se debruçam sobre a epopeia lusíada, qual seja, o de Abraão. Em seguida, o episódio da máquina do mundo tornou-se objeto de estudo, pois ajuda-nos a compreender o providencialismo e suas características. Por fim, o éthos de Vasco da Gama é analisado de perto, com o intuito de pensar que tipo de herói protagonizou a epopeia camoniana.

Palavras-chave: Os Lusíadas; providencialismo; heroísmo.

ABSTRACT: It is not new at this time to say that Camões imitated Greco-Roman poetry, especially the epics of Homer and Virgil. However, the conduct of Vasco da Gama does not always adjust to the actions of Achilles or Odysseus because in the sixteenth century there is a providential conception of time, that is, the existence of a unique and ubiquitous God that assists the world's disconcerts is assumed. Thus, this article unfolds in three moments. In the first, a model of conduct is not always considered by readers who are leaning on the Lusíadas epic, namely Abraham. Then, the episode of the world machine became the object of study, because it helps us to understand the providentialism and its characteristics. Finally, the ethos of Vasco da Gama is analyzed closely, in order to think what kind of hero starred in the epic Camonian.

Keywords: Os Lusíadas; providentialism; heroism.

\section{Introdução}

Com Os Lusíadas (1572), Camões elaborou um canto épico que tem por matéria a harmonia do organismo social português, e não um herói detentor de atributos sobre-humanos. Sua poesia, por outras palavras, canta a coesão do corpo místico e, concomitantemente, o respeito às hierarquias, condições sem 
as quais não haveria concórdia entre os membros do reino lusitano. Se Vasco da Gama assumiu o protagonismo no que diz respeito à viagem ultramarina rumo às Índias, é porque soube não apenas lutar pela ordem geral, mas também aceitar o lugar hierárquico que lhe foi designado. A presença do herói, neste caso em particular, supria a falta "física" do rei e, ao mesmo tempo, encarnava seu "corpo político" e tudo o que ele representava. ${ }^{1}$ Por outro lado, ele também agia como instrumento da Providência, muitas vezes contando com o amparo do Criador ao longo de seu itinerário.

Embora tenha imitado poetas gregos e latinos, muitas vezes recorrendo aos atributos grandiosos dos heróis homéricos para amplificar a nobreza lusitana, a conduta de Vasco da Gama assemelha-se também (e sobretudo) ao comportamento das personagens bíblicas. É o caso, por exemplo, de Abraão, que se comporta

como perfeito fiel e devoto de Javé, e apenas Dele: como perfeito monoteísta. Em tudo o que nos é relatado sobre ele e, depois, sobre seus filhos, jamais se invocam aqueles "deuses estrangeiros", não há o menor vestígio do politeísmo que governava em toda parte os espíritos e corações (...). É apenas a Javé que ele consagra um culto, erigindo-Lhe, aqui e ali, altares para oferecer-Lhe sacrifícios (BOTTÈRO, 2011, p.242).

De acordo com Jean-Louis Ska, o objetivo de Odisseu era retornar à pátria e reencontrar seus familiares, percurso contrário àquele assumido por Abraão, que partiu com sua família deixando a casa de seu pai e sem perspectiva de retorno. Se, no primeiro caso, a vida proporciona um itinerário tumultuoso repleto de provações, mas ao final conduz o herói de volta ao mundo conhecido, para Abraão a promessa tem por objeto o desconhecido, ou seja, corre-se o risco de tudo perder:

Ulisses volta para casa e encontra seu pai Laerte; Abraão deixa seu pai e vai para longe de sua casa, definitivamente. Ulisses encontra seu filho Telêmaco; Abraão é convidado a sacrificar seu filho. Ulisses volta para libertar a fiel Penélope dos pretendentes que querem desposá-la; Abraão parte para um destino desconhecido com uma esposa estéril, que não lhe garantiu descendência (SKA, 2009, p.25).

Há, portanto, uma distância considerável entre a odisseia do herói grego e o êxodo do patriarca que partiu de Ur dos caldeus para constituir uma família em terras longínquas. Em se tratando particularmente do mais antigo antepassado do povo de Israel, é preciso levar em consideração o contexto no qual a narrativa foi construída. De acordo com Thomas Römer, os acontecimentos de 597 e 587/586 a.C. produziram uma "crise" na identidade coletiva judaica, causando o desmoronamento dos pilares tradicionais "que suportavam a coerência ideológica e política de um Estado monárquico no Oriente Próximo antigo" (RÖMER, 2017, p.208), afinal, o templo havia sido destruído e o rei, deportado. Os israelitas buscaram superar a crise em andamento, especialmente grupos associados à aristocracia judaíta. Como se sabe, Ciro II, rei da Pérsia, depois de assumir o controle do território babilônico, adotou uma postura de tolerância em relação às populações submissas, permitindo que os exilados voltassem para suas terras e restaurassem os cultos locais.

${ }^{1}$ Sobre a relação entre o herói e o rei, ver: (LUZ, 2007, p.558-560). 
Foi no interior da Golah, desse grupo de judeus que retornaram do exílio, que surgiu uma parcela importante dos textos bíblicos que procurou explicar não apenas a destruição de Jerusalém, mas também o papel de Javé neste acontecimento.

A história deuteronomista, que se desdobra nos livros de Josué, Juízes, Samuel e Reis², foi escrita por funcionários de alguma forma inspirados pelas reformas religiosas promovidas à época de Josias (648-609 a. C.). Incomodados com o fim da monarquia, eles buscaram explicar o que ocasionou o exílio babilônico, retomando a história de Moisés e avançando até a destruição de Jerusalém e a deportação da aristocracia. Foram eles os responsáveis pela retomada dos antigos rolos da época assíria e pela organização da sua história. Os acontecimentos negativos que culminaram no exílio foram apresentados como desdobramento da desobediência do povo e de seus chefes diante dos termos da aliança firmada com Yahweh. Assim, a divisão da monarquia em dois reinos e, posteriormente, as invasões assíria e babilônica, teriam sido ocasionadas pelo próprio deus dos israelitas, como forma de punir os transgressores que praticavam idolatria, ou seja, se "prostituíam" adorando divindades estrangeiras. Logo, não se trata de uma vitória dos deuses babilônicos, mas de uma manipulação dos estrangeiros por parte de Yahweh para punir a inconstância e os pecados dos israelitas. Prepara-se o terreno, portanto, para afirmações de cunho propriamente monoteísta.

Abraão parece reunir em si virtudes que faltaram à sua descendência, como fé, fidelidade e constância (perante os desígnios divinos). Embora seja comum a afirmação de que não há heroísmo entre as personagens bíblicas, parece-nos verossímil pensar que, no caso de uma religião monoteísta, configura-se um novo éthos, um novo comportamento. Este comportamento fica ainda mais claro quando levamos em consideração os escritos sacerdotais, que foram redigidos por membros do clero no início da época persa. Sua perspectiva encontra-se presente, por exemplo, em boa parte dos textos que compõem a Torá, como é o caso dos livros de Gênesis, Êxodo e Levítico. Para os autores sacerdotais, o único tempo que conta é o das origens (origem do mundo, tempo dos Patriarcas e de Moisés). Não interessa a eles a história da monarquia, tampouco a perda da terra, assuntos tão caros à perspectiva deuteronomista. As regras que importam à escrita sacerdotal encontram-se impostas desde as origens: a interdição de consumir sangue (estabelecida após o dilúvio), a circuncisão (ordenada por Abraão), a Páscoa, assim como as leis rituais e sacrificiais. É com o movimento sacerdotal que o discurso segregacionista da história deuteronomista passa a ser atenuado, dando abertura para um monoteísmo inclusivo que pensa Yahweh como criador de todos os povos.

Segundo a narrativa sacerdotal, todas as instituições cultuais e rituais são dadas aos Patriarcas e a Israel antes da organização política de Israel, o que quer dizer que não há necessidade nem de terra, nem de reino para poder venerar Yahweh de maneira adequada. Esse desacoplamento do culto de Yahweh das instituições políticas e da ligação com a terra prepara, de certa maneira, a ideia de uma separação entre o domínio do religioso e o domínio do político (RÖMER, 2017, p.220).

\footnotetext{
2 O livro de Josué descreve a conquista da terra prometida; o livro dos Juízes dedica-se às vicissitudes das tribos de Israel durante um período agitado, marcado por invasões e ocupações estrangeiras; com os livros de Samuel, assistimos ao início da monarquia, primeiro com Saul e depois com Davi. Os livros dos Reis narram os principais eventos do reinado de Salomão e depois dos reinos divididos, encerrando com a queda de Samaria e, posteriormente, de Jerusalém.
} 
O papel desempenhado por Abraão encontra-se alinhado a esta concepção sacerdotal da divindade, como fica claro no episódio envolvendo o sacrifício de Isaque, no qual o patriarca demonstrou constância na fé. O caráter incondicional da promessa feita a Abraão, uma vez que Yahweh não exigiu qualquer contraparte, ajusta-se a uma perspectiva monoteísta, acentuada especialmente por meio dos escritos sacerdotais.

Para compreender melhor o papel desempenhado por Vasco da Gama, além de levar em consideração a personagem bíblica supracitada, é preciso compreender as características de uma história providencialista e as virtudes que integravam o éthos do protagonista de Camões. Para tanto, investigaremos o episódio da máquina do mundo e algumas ações de Gama retratadas no poema. Parte-se da hipótese de que o poeta emulou as epopeias antigas, retomando características dos antigos heróis greco-romanos, mas também imitou modelos de comportamento afinados ao texto bíblico, destacando virtudes que outrora fundamentaram o éthos de Abraão, como constância na fé, obediência etc.

\section{A máquina do mundo}

Pensemos, agora, nas especificidades da história cristã portuguesa: em primeiro lugar, é preciso levar em consideração que o tempo, no século XVI, é considerado criação de Deus. Sendo assim, todas as ações de Vasco da Gama incluem, necessariamente, a presença de Deus, que se repete em todas as diferenças históricas. Não há punição que não Lhe diga respeito, não há acontecimento no qual Ele não esteja presente. Há, porém, limitação humana, pois o homem não entende com clareza os sentidos da justiça divina. Se todos os momentos históricos são análogos, justamente por implicarem a identidade de Deus, deduz-se que a história pode ensinar maneiras de agir conformadas à vontade da Providência. O episódio da máquina do mundo, situado nos cantos finais da epopeia, pode ajudar a compreender este sentido providencialista da história portuguesa.

Antes de apresentar-Ihe a máquina do mundo, Tétis lançou uma advertência a Vasco da Gama:

Faz-te mercê, barão, a Sapiência Suprema de, cos olhos corporais, Veres que não pode a vã ciência Dos errados e míseros mortais. Segue-me firme e forte, com prudência, Por este monte espesso, tu cos mais." Assim Ihe diz, e o guia por um mato Árduo, difícil, duro a humano trato. (CAMÕES, 2008, X, 76).

De acordo com Hansen, Vasco da Gama contemplou a "forma invisibilíssima ou substância metafísica do universo", algo que não poderia ser apreendido pela ciência humana. O herói é convidado a seguir, com prudência, os passos de Tétis. Neste caso, a reta razão de Gama seria iluminada pela Graça divina, Causa Primeira. A prudência, portanto, apenas seria possível caso a ação do protagonista se ajustasse aos desígnios 
da Providência. O mato "Árduo, difícil, duro a humano trato", de acordo com Hansen, é uma "figuração que encontramos em textos platônicos dos séculos XV e XVI" (HANSEN, 2005, p.184). No caso, o mato seria uma alegoria da vida sensível, que é temporariamente deixada de lado. É possível notar uma aproximação entre este episódio d'Os Lusíadas e o terceto inicial da Divina Comédia: "No meio do caminho em nossa vida, / eu me encontrei por uma selva escura/ porque a direita via era perdida" (ALIGHIERI, 2005, p.31). De acordo com Vasco Graça Moura, a selva representa os erros e desvios da condição humana. Há, portanto, um nexo entre os dois passos, pois os protagonistas Dante e Vasco da Gama abandonam aquilo que é próprio da condição humana para participar de outro plano, inacessível aos "errados e míseros mortais". Ambas as personagens, com "olhos corporais", testemunham, graças à intervenção da Providência, eventos que escapam à "vã ciência".

A máquina do mundo é apresentada como um artifício. O termo máquina, do grego mékhané, designa "qualquer invenção produzida com arte pela inteligência artificiosa, a métis" (HANSEN, 2005, p.185). De acordo com Hansen, a "forma do universo revelada na máquina do mundo é artifício do engenho divino, que a gera com razão, doutrina e ordem. A máquina do mundo é o universo fabricado artificiosamente pelo engenho de Deus, o autor máximo" (HANSEN, 2005, p.185). Hansen, em seguida, afirma que ela é

finita, como efeito e signo fabricados por artifício divino, mas ilimitada [...] Sua racionalidade atesta que é divina a arte inventada pelo Arquétipo, a pura esfera inteligível, nua, pura e invisível de Deus. Absolutamente indeterminado e inacessível à razão humana, Deus a cerca com seus nove coros de anjos, movendo-a com Amor (HANSEN, 2005, p.186).

A máquina reproduzida por Camões é etérea e elemental: a parte etérea é celestial, feita da "quintessência imutável e lúcida"; a parte elemental, por sua vez, "corresponde aos orbes compostos dos quatro elementos pitagóricos, ar, terra, água e fogo" (HANSEN, 2005, p.186). Na sua epopeia, Camões retrata os orbes planetários, indica a complexidade de seu curso, afirma a imobilidade da Terra e discorre sobre os quatro elementos dos quais ela é feita.

Debaixo deste grande Firmamento, Vês o céu de Saturno, Deus antigo; Júpiter logo faz o movimento,

E Marte abaixo, bélico inimigo;

O claro Olho do céu, no quarto assento,

E Vênus, que os amores traz consigo;

Mercúrio, de eloquência soberana;

Com três rostos, debaixo vai Diana.

Em todos estes orbes, diferente Curso verás, nuns grave e noutros leve, Ora fogem do Centro longamente, Ora da Terra estão caminho breve, Bem como quis o Padre onipotente, Que o fogo fez e o ar, o vento e neve, Os quais verás que jazem mais adentro E têm co Mar e Terra por seu centro. 
Estes versos provavelmente foram emulados em Prosopopeia, pois também aqui são descritos os quatro elementos que formam o Universo e a configuração das Estrelas Fixas, tal como foi preconizada por Ptolomeu:

\author{
O marchetado Carro do seu Febo \\ Celebre o Sulmonês, com falsa pompa, \\ E a ruína cantando do mancebo, \\ Com importuna voz, os ares rompa. \\ Que, posto que do seu licor não bebo, \\ À fama espero dar tão viva trompa, \\ Que a grandeza de vossos feitos cante, \\ Com som que ar, fogo, mar e terra espante. \\ (TEIXEIRA, 1972, p.125). \\ As luzentes estrelas cintilavam, \\ E no estanhado mar resplandeciam, \\ Que, dado que no céu fixas estavam, \\ Estar no licor salso pareciam. \\ Este passo os sentidos preparavam \\ Àqueles que d'amor puro viviam, \\ Que, estando de seu centro e fim ausentes, \\ Com alma e com vontade estão presentes. \\ (TEIXEIRA, 1972, p.126).
}

Apropriando-se da cosmologia de Ptolomeu, Camões e Bento Teixeira aderiram ao geocentrismo, ou seja, a Terra, esférica e imóvel, foi situada no centro do universo. Em torno dela girariam os nove orbes materiais. Para Ptolomeu, os planetas não reproduzem círculos perfeitos, mas trajetórias muito complexas que podem ser matematicamente calculadas. Na sequência, encontra-se o Céu das Estrelas Fixas, mencionado por Tétis na estrofe 88, e o Primeiro Móvel, que gira e faz mover os outros orbes. Acima dele, por fim, localiza-se o Empíreo, que é feito de éter imaterial e guarda as almas puras. A luz que exala "cega o olhar sensível e a razão humana, incapazes de vê-lo e entendê-lo" (HANSEN, 2005, p.187).

Camões admitiu, como bom escolástico, a impossibilidade de definir Deus: “[...] o que é Deus, ninguém o entende, / Que a tanto o engenho humano não se estende" (CAMÕES, 2008, X, 80, p.302). Dante Alighieri insistiu nesta propriedade indescritível do Artífice quando adentrou o último círculo do Paraíso. 0 Empíreo, no caso, "é pura Luz intelectual - pois vem de Deus, Intelecto infinito - plena de Amor infinito, verdadeira Alegria do Bem que transcende toda doçura" (HANSEN, 2010, p.36). A figura circular que chega aos olhos de Dante e de Camões repõe a antiga definição de Deus como "círculo infinito e perfeito que tem o centro em toda parte e a circunferência em nenhuma" (HANSEN, 2005, p.186). Dante, no caso, entende o enigma sem poder descrevê-lo com palavras. Em Camões, Deus, que também é comparado ao círculo infinito e perfeito, "desce pelos vários orbes circulares e finitos como Amor da sua Forma invisibilíssima, que neles participa analogicamente" (HANSEN, 2005, p.186). 
Torquato Tasso também mencionou e descreveu o Empíreo, reafirmando a cosmologia ptolomaica e, provavelmente, emulando a Commedia de Dante:

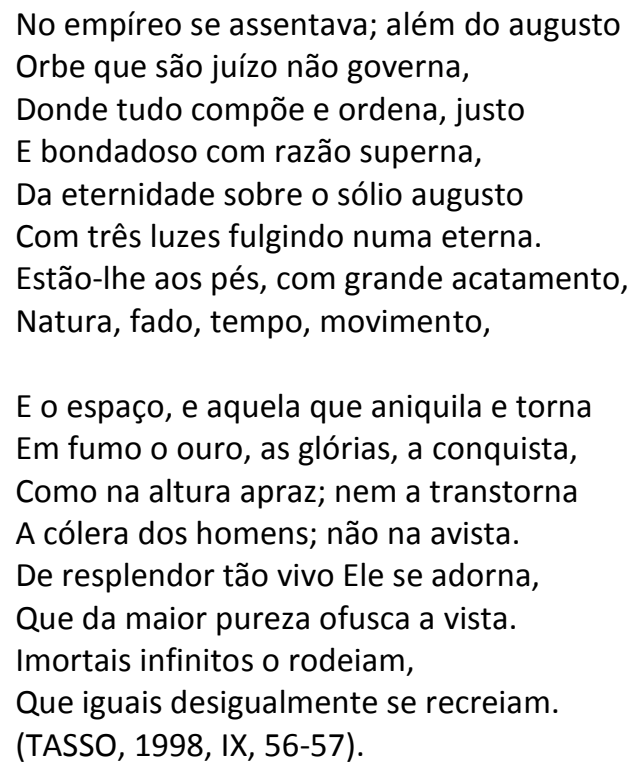

Tasso menciona o orbe que o juízo humano não apreende, pois é regido pela "razão superna". As "três luzes" aludem à trindade, figurada por Dante da seguinte maneira: "E na profunda e clara substância/ do alto lume três círculos vi vir/ de três cores e de uma continência" (ALIGHIERI, 2005, XXXIII, 115-117, p.884885). O resplendor que orna o Criador "ofusca a vista", afirmou o poeta. Nota-se que, tal como Dante e Camões, Tasso utilizou a metáfora da luz para justificar a impossibilidade de descrever aquilo que a razão humana não governa. Isto confirma o quão privilegiado foi Vasco da Gama ao contemplar as feições da "máquina do mundo", artifício supremo:

Aqui um globo vêem no ar, que o lume Claríssimo por ele penetrava, De modo que o seu centro está evidente, Com a sua superfície, claramente.

Qual a matéria seja não se enxerga, Mas enxerga-se bem que está composto De vários orbes, que a Divina verga Compôs, e um centro a todos só tem posto. Volvendo, ora se abaixe, ora se erga, Nunca se ergue ou se abaixa, e num mesmo rosto Por toda a parte tem; e em toda a parte Começa e acaba, enfim, por divina arte. (CAMÕES, 2008, X, 77-78).

Dante, Camões e Tasso afirmaram poeticamente que a essência de Deus, "que é absolutamente sublime, invisível, indizível e impensável" (HANSEN, 2010, p.40), é indefinível. Na estrofe 78 do canto X, Camões adota a definição euclidiana da esfera como "superfície de revolução produzida pelo movimento da 
circunferência em torno do diâmetro, movimento que faz que os círculos cresçam até o meridiano e depois diminuam" (HANSEN, 2005, p.186). Quando Deus se mostra a Dante e permite que Vasco da Gama testemunhe a máquina do mundo, as luzes e o esclarecimento são apenas "prefácios de sombra", ou seja, é impossível aos olhos mortais entender uma Essência que a razão humana desconhece. A Luz absoluta, que se manifesta surpreendentemente no canto XXXIII do Paraíso e se apresenta a Dante como enigma, "ofusca a vista", nas palavras de Torquato Tasso, e em Camões "a vista cega" (CAMÕES, 2008, X, 81, p.302). O olhar humano contempla somente aquilo que a razão consegue assimilar, ou seja, é impossível que um homem consiga desmembrar o artifício que fundamenta a máquina do mundo, pois "Quem cerca em derredor este rotundo/ Globo e sua superfície tão limada,/ É Deus" (CAMÕES, 2008, X, 88, p.302).

A organicidade da obra de Camões parece, em alguns momentos, se explicar em retrospecto, ou seja, há passagens iniciais que só entendemos com propriedade ao final do poema. Após falar do Empíreo, Camões discorreu sobre Deus, "que por segundas/ Causas obra no Mundo, tudo manda" (CAMÕES, 2008, X, 85, p.304). Esta causa segunda muitas vezes é incorporada pelos deuses pagãos. Tétis afirma que a encenação das deidades mitológicas pretende somente deleitar a audiência. Para tanto, a deusa nega a si própria quando admite: “eu, Saturno e Jano, / Júpiter, Juno, fomos fabulosos, / Fingidos de mortal e cego engano" (CAMÕES, 2008, X, 82, p.303). A poesia está para terminar, e a alegoria já não se faz mais necessária.

A máquina do mundo é finita, sendo um artifício da Providência, mas é ilimitado por conter informações e revelações que o "olho físico" não contempla a não ser em ocasiões muito especiais. Virgílio, alegoria da Razão, e Beatriz, alegoria do amor, orientam Dante rumo à contemplação daquilo que o ser vivo não pode apreender e, por isso, os enigmas são parcialmente compreendidos. Da mesma forma, a Causa Segunda representada pela deusa Tétis convida Vasco da Gama a contemplar uma imagem artificiosa e, no entanto, invisível à razão humana, que é passageira. A máquina do mundo, que pode ser entendida como o maior de todos os artifícios da epopeia de Camões, dissimula o verdadeiro aspecto da Causa Primeira e, ao mesmo tempo, desengana aquele que a contempla. O Amor orienta os itinerários do protagonista, a razão ajuda o leitor a "ver" a partir do olhar prudente do narrador e a ordenação/disposição dos quadros forja uma memória e retrata os vários estágios da condição humana.

Camões, na esteira de Dante, adota a concepção ptolomaica, que

tinha sido desmentida pelas navegações do século XV [...] quando Camões termina Os Lusíadas, em 1567, as inovações e a velha fidalguia já tinham sido substituídas pela Inquisição, pela censura intelectual, pela perseguição religiosa e pela mentalidade mercantil. O canto presente faz a apologia do projeto imperial da conquista do mundo pela fé e pelas armas, e, simultaneamente, o poeta afirma que vem cantar "a gente surda e endurecida", na estrofe 145 do Canto X (HANSEN, 2005, p.191).

A poesia camoniana precisou passar pela censura inquisitorial e adaptar-se à ortodoxia então vigente. Os elementos teológicos e políticos que conferiam sentido à máquina do mundo deveriam ser manuseados com prudência. Hansen adverte: 
A alegoria da máquina é, nesse sentido, um meio poético-metafísico com que Camões figura a alma portuguesa em estado de receptividade extática da unidade invisível do divino. A união sexual dos navegantes com as ninfas aquáticas e a de Vasco da Gama com Tétis alegorizam o casamento de Portugal com o mar. A visão da máquina do mundo alegoriza seu contato extático com o princípio metafísico, o Bem para além do movimento aparente das esferas, que fundamenta e orienta providencialmente a união e a viagem por meio de Vênus, seu instrumento ou causa segunda. Em outras partes, o episódio da máquina do mundo fundamenta o domínio físico do mar e das novas terras da África, da Ásia e da América como domínio físico teológico-político da monarquia católica sobre regiões e religiões gentias e infiéis, divinizando a história de Portugal (HANSEN, 2005, p.191).

Quando contemplam o artifício divino por meio da máquina do mundo, Dante e Vasco da Gama assimilam a verdade sem poder dizê-la. Quando apreciam aquilo que a razão humana não pode inventariar, o leitor apreende a pintura poética sem poder defini-la. Assim como Dante, Vasco da Gama inicialmente presenciou trevas, infortúnios, labores e perigos. Ao final da trajetória, ambos se afastam da "selva" que representa a condição humana para participar de um plano Providencial repleto de luz e esclarecimento. A finalidade que Dante atribui à Commedia, em uma carta dirigida ao seu protetor Cangrande della Scala, parece orientar também os itinerários d'Os Lusíadas: "remover os que vivem nesta vida do estado de miséria e levá-los para o estado de felicidade" (HANSEN, 2010, p.11).

As revelações sobre a máquina do mundo só ocorreram ao final da jornada do herói, depois de ter passado por grandes desventuras. De acordo com Corte-Real, a Providência comumente age de forma misteriosa:

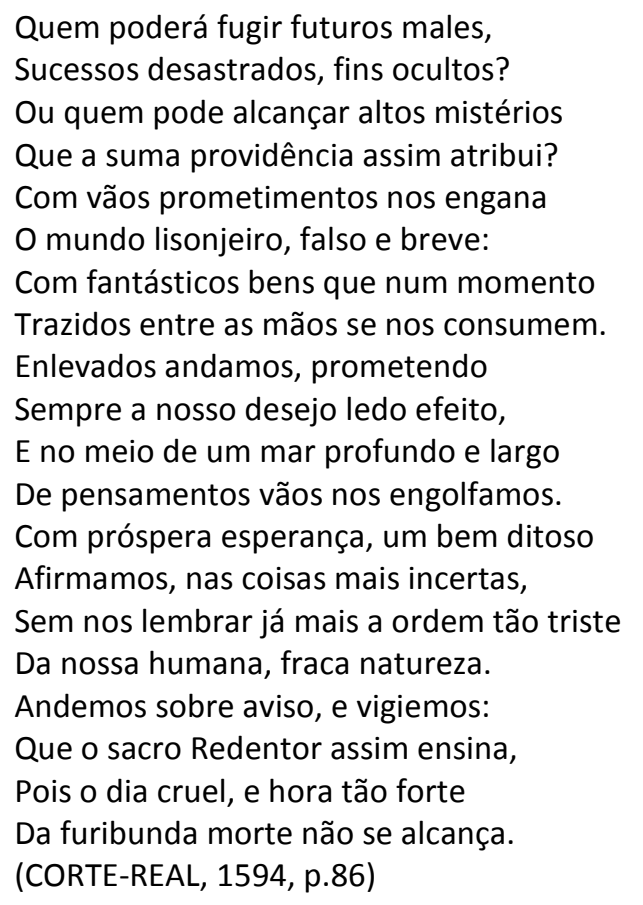

Priorizar os bens mundanos em prol dos bens duradouros implica ignorar que, no fim, todos vão ser julgados a partir dos mesmos critérios: 
Vede os confusos montes dos defuntos

No mundo vede que tudo é possível,

Os vulgares, e os nobres vereis juntos

Com estrago espantoso, e mal terrível.

Neste dia cruel vereis transuntos

Desta vida mortal o caso horrível,

Que o pobre, o rico, e fraco, e o que é mais forte

São todos em geral iguais na morte.

(CORTE-REAL, 1594, p.165)

Após desenganar-se perante as aparências, o mais seguro seria contar com a intervenção de Deus:

Incerto é o fim das coisas, e o sucesso

Do mal, ou bem futuro a nós oculto,

Pois temos, por passar tão vários casos:

Chamar sempre por Deus é o mais seguro.

(CORTE-REAL, 1594, p.127)

Os mistérios podem ser apreendidos de formas variadas, como deixa ver o poeta ao discorrer sobre a maneira como o vulgo os concebe:

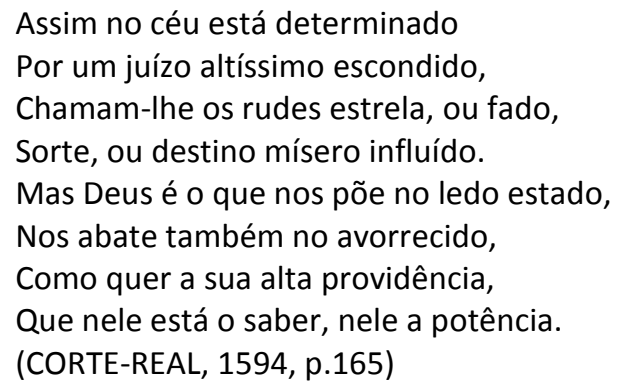

Seria próprio do néscio, portanto, levar em consideração as aparências e perder de vista o verdadeiro bem:

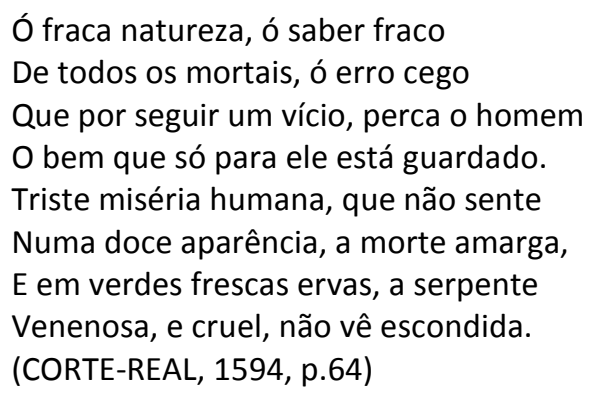

De um lado, há o altíssimo juízo de Deus, oculto aos olhos, mas manifesto na história; de outro, a cegueira do vulgo, que enxerga o que lhe apetece e despreza o bem duradouro. A poesia parece retirar dos exemplos históricos e/ou fabulosos os fundamentos ou predicados deste sentimento. Com encômios e vitupérios, proporciona-se o desengano do leitor. Onde muitos contemplam uma contradição 
(epopeia/antiepopeia), poder-se-ia observar a proposta de uma harmonia cósmica centrada no reto direcionamento do amor e sintetizada artificialmente no globo da etérea e elementar máquina do mundo.

\section{O heroísmo de Vasco da Gama}

António José Saraiva atribuiu às personagens d'Os lusíadas falta de vida e ânimo, supondo a inexistência do heroísmo entre elas. O autor desconfia que o foco da narrativa sejam as deidades mitológicas, e não Vasco da Gama e seus pares. Muitas vezes as personagens mitológicas, sob o efeito de prosopopeia, são consideradas aquelas que realmente agem no decorrer das narrativas épicas. Saraiva afirma que os deuses não são "simples retórica, mas as figuras com que se ata e desata a própria fábula do poema" e considera que "n'Os Lusíadas não há outras personagens vivas senão os deuses", o que delega aos heróis um papel de meros coadjuvantes, que "limitam-se a presenciar, a esperar e a agradecer" (SARAIVA, 1980, p.158166). Se entendermos na mitologia uma função alegórica, que muitas vezes dá a entender a presença dos desígnios da providência, a afirmação de Saraiva se justifica. Contudo, o herói não apenas presencia, espera e agradece como também lê, nas entrelinhas, a matéria providencial e age como instrumento de Deus, para a materialização de suas vontades. Vejamos como estes elementos aparecem no poema.

A fidelidade ajuíza os homens quanto aos caminhos retos que devem ser percorridos. Os súditos deveriam incorporar os desígnios que partiam da Coroa portuguesa e abraçá-los independentemente da ocasião. Quando desembarca nas proximidades da cidade de Melinde, por exemplo, Vasco da Gama é bem recepcionado, mas, precavido, o herói opta por não desembarcar de imediato e envia um emissário até o rei para justificar a sua conduta:

\footnotetext{
E não cuides, ó Rei, que não saísse

O nosso Capitão esclarecido

A ver-te ou a servir-te, porque visse

Ou suspeitasse em ti peito fingido;

Mas saberás que o fez, por que comprisse

O regimento, em tudo obedecido,

De seu Rei, que lhe manda que não saia,

Deixando a frota, em nenhum porto ou praia.

E, porque é de vassalos o exercício,

Que os membros têm, regidos da cabeça,

Não quererás, pois tens de Rei o ofício,

Que ninguém a seu Rei desobedeça [...];

(CAMÕES, 2008, II, 83-84)
}

Camões recorre à metáfora do corpo místico para discorrer sobre a função da "cabeça" do reino e de seus "membros". É obrigação do súdito, portanto, cumprir o regimento que the compete e manter-se fiel a ele. No caso, o emissário afirma ao rei que Gama não nutria suspeitas em relação à sua boa intenção quando se recusou a desembarcar, mas o fez por respeito à cabeça do reino. 
Após a deliberação do emissário, o rei de Melinde se mostra impressionado com a fidelidade de Vasco da Gama:

\author{
[...] E o Rei ilustre, o peito obediente \\ Dos Portugueses na alma imaginando, \\ Tinha por valor grande e mui subido \\ $O$ do Rei que é tão longe obedecido. \\ (CAMÕES, 2008, II, 85)
}

Apesar de desejar o desembarque imediato dos navegantes lusitanos, o rei aceita a resolução do herói, pois reconhece na postura de Vasco da Gama algo ilustre a ser preservado:

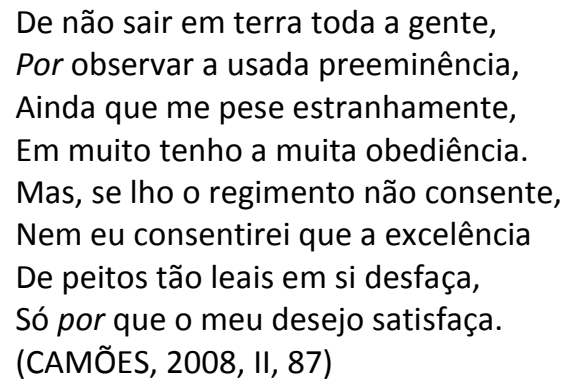

O rei de Melinde tem em alta estima a preeminência, ou seja, o respeito às ordens superiores. Na sua posição de rei, esta disposição de ânimo é essencial para a articulação e administração de um Império. Ele, então, age de maneira contrária à de Baco: longe de criar qualquer ressentimento contra os portugueses, ele coloca em segundo plano suas vontades e prioriza a determinação dos visitantes estrangeiros. A ausência de vaidade demonstra a boa disposição do rei, ao contrário dos mouros que, até então, haviam travado conhecimento com Gama e sua tripulação. É sob a égide deste juízo prudente que, posteriormente, o rei mouro e o herói lusitano travariam amizade. Por outro lado, se o rei de Melinde mostra-se surpreendido, é por desígnio providencial que ilumina seu entendimento. Nesta leitura, Vasco da Gama age como instrumento que apresenta ao infiel a verdade por intermédio da Revelação. Não por acaso, o poeta deixa transparecer a centralidade do papel desempenhado pelo rei em questão, referindo-se a ele como "Rei mais amigo", "Sublime Rei”, "Rei benigno", "Rei ilustre”, "Rei Pagão”, e "Pagão benigno”.

A fidelidade, na épica camoniana, é recompensada pela obrigação da reciprocidade, isto é, o ato de servir pressupõe certos benefícios àquele que serve como, por exemplo, em ocasiões nas quais o rei confia ao súdito uma grande responsabilidade. O poeta d'Os Lusíadas contempla este lugar comum recorrendo à tópica da amizade que se estabelece entre o rei português e o nauta Vasco da Gama, quando este último é designado para liderar a empresa ultramarina:

E com rogo e palavras amorosas,

Que é um mando nos Reis que a mais obriga,

Me disse: "As cousas árduas e lustrosas 
Se alcançam com trabalho e com fadiga;

Faz as pessoas altas e famosas

A vida que se perde e que periga,

Que, quando ao medo infame não se rende,

Então, se menos dura, mais se estende.

Eu vos tenho entre todos escolhido

Para uma empresa, qual a vós se deve,

Trabalho ilustre, duro e esclarecido,

O que eu sei que por mi vos será leve."

Não sofri mais, mas logo: "Ó Rei subido,

Aventurar-me a ferro, a fogo, a neve,

É tão pouco por vós, que mais me pena

Ser esta vida cousa tão pequena."

(CAMÕES, 2008, IV, 78-79)

Neste episódio, o rei D. Manuel menciona a bravura e a experiência de Vasco da Gama e, por isso, Ihe concede uma missão ilustre. Antes disso, o rei disserta sobre a necessidade e o valor do "trabalho", quando visa o bem-estar geral: é esta motivação que, de fato, confere glória e fama aos homens munidos de princípios, garante o rei. Recorrendo ao lugar da amizade, o rei concede ao protagonista trabalho "ilustre, duro e esclarecido". Estas instruções e o reconhecimento movem o herói que, animoso, acata as designações prontamente. Ao final, o poeta recorre à tópica da brevidade da vida, presente, por exemplo, nos poemas de Homero, como no caso em que é retratado o ressentimento de Aquiles perante a sua condição de mortal. Havia uma fronteira intransponível que distinguia a condição humana da condição das divindades: o homem, na épica de Homero, sabe que terá vida curta, enquanto os deuses viviam eternamente. Em Camões, este lugar recobra outra dimensão: a imortalidade da alma, possibilidade cristã de salvação e vida eterna. Esta finalidade seria alcançada se o vassalo cristão se dispusesse a cumprir seu legado, definido, legitimado e sugerido pelo rei, representante de Cristo na terra e detentor de um lugar sacro e hierarquicamente sem equivalência.

Em outro momento, quando a nau de Vasco da Gama foi castigada por uma tempestade, o protagonista recorreu ao remédio "santo e forte" e lamentou, como era costume, a morte em alto-mar:

Vendo Vasco da Gama que tão perto

Do fim de seu desejo se perdia,

Vendo ora o mar até o Inferno aberto,

Ora com nova fúria ao céu subia,

Confuso de temor, da vida incerto,

Onde nenhum remédio Ihe valia,

Chama aquele Remédio santo e forte,

Que o impossível pode, desta sorte:

“Divina Guarda, angélica, celeste, Que os Céus, o Mar e Terra senhoreias:

$\mathrm{Tu}$, que a todo Israel refúgio deste

Por metade das águas Eritréias;

$\mathrm{Tu}$, que livraste Paulo e defendeste

Das sirtes arenosas e ondas feias,

E guardaste, cos filhos, o segundo 
Povoador do alagado e vácuo mundo:

Se tenho novos medos perigosos

Doutra Cila e Caríbdis já passados,

Outras Sirtes e baxos arenosos,

Outros Acroceráunios infamados,

No fim de tantos casos trabalhosos,

Por que somos de Ti desamparados,

Se este nosso trabalho não Te ofende,

Mas antes Teu serviço só pretende?

Oh! Ditosos aqueles que puderam

Entre as agudas lanças Africanas

Morrer enquanto fortes sustiveram

A santa Fé nas terras Mauritanas!

De quem feitos ilustres se souberam,

De quem ficam memórias soberanas,

De quem se ganha a vida, com perde-la,

Doce fazendo a morte as honras dela!"

(CAMÕES, 2008, VI, 80-83).

Como se pode ver nestas oitavas, além da passagem dos hebreus pelo Mar Vermelho, Camões faz menção à tempestade bíblica que acometeu Paulo e ao dilúvio. Com o propósito de amplificar o terror vivenciado pelos marinheiros, o poeta imita a Eneida e uma ode de Horácio ao mencionar os monstros mitológicos e descrever o movimento das ondas. Vênus, causa segunda, foi a responsável pelo abrandamento da fúria dos ventos, que atacavam a nau como "touros indômitos".

As ações de Vasco da Gama muitas vezes reforçam a hierarquia política e, portanto, as ambições de seu rei. Em outros momentos, quando se vê ameaçado, o protagonista solicita intervenção divina. Mas seria lícito dizer que o éthos de Gama é absolutamente pautado na virtude da prudência? Convém entender, a princípio, como o conceito de prudência foi concebido no tempo de Camões. Em trabalho sobre a prudência nos escritos de Aristóteles, Pierre Aubenque afirma que a existência do homem prudente precede a determinação da essência/natureza da prudência (phrónesis), isto é, o homem prudente não é apenas o intérprete da reta regra, mas o portador vivo da norma e, portanto, a personificação da regra. Esta deve ser entendida como critério definidor da justa medida que, por sinal, é discernível somente aos olhos do homem dotado de phrónesis. O homem prudente é o único capaz de fornecer um julgamento reto e, por esse motivo, consegue deliberar bem tendo em vista uma ação circunstancial e contingente. Por outras palavras, não há prudência sem, antes, haver um modelo de conduta a ser seguido. A vida feliz, finalidade última que tangencia a ética aristotélica, envolve justamente a superação das finalidades particulares e a priorização dos bens humanos. Por esta razão, Aristóteles faz do homem o centro de sua ética sem divinizá-lo, como nos lembra Aubenque. A prudência, então, seria "o substituto propriamente humano de uma Providência que falha" (AUBENQUE, 2008, p.155).

Desta forma, a phrónesis é entendida como uma disposição prática responsável pelo reconhecimento das virtudes morais. Felipe Charbel afirma que a escolha (proairesis) é central na definição do agir prudente em Aristóteles, pois é por meio dela que se recorre aos meios adequados para se atingir o fim proposto. 
Assim, não basta "saber o que é justo e nobilitante. É preciso, acima de tudo, saber escolher o justo, transformá-lo em ação e conduta", o que é possível através da "ponderação de cada acidente, de cada lance fortuito a que os homens estão sujeitos" (TEIXEIRA, 2008, p.60). O desejo de ser bom e de ocasionar o bem principia a resolução acertada e o cálculo racional a ser aplicado perante a contingência das coisas humanas. ${ }^{3}$

Tomás de Aquino também busca entender o conceito de prudência. Em 2005, Jean Lauand editou um tomo da Suma Teológica no qual o teólogo, em diálogo com Aristóteles, discorreu sobre o conceito em questão. Ele define esta virtude como recta ratio agibilium (reta razão aplicada ao agir), uma forma de razão prática que leva o homem a priorizar o bem comum em detrimento de suas vontades particulares (AQUINO, 2005, p.156-171). Esta premissa afina-se aos dizeres de Aristóteles quando, em sua Ética a Nicômaco, afirmou que a sensatez é a capacidade de agir com prudência e temperança, o que implica levar em consideração o bem-estar geral (ARISTÓTELES, 2009, p.132-134). A valorização do bem comum, conceito que integra a matriz das reflexões de Aquino sobre a prudência, implica o abandono das vaidades, dos laços profanos e iníquos, e a total devoção ao corpo místico da Igreja que, em tese, deveria ser regido organicamente, de modo a unir todos os seus agregados/subordinados em torno de protocolos inteiramente cristãos. Tal como o corpo humano, que deve manter seus membros em harmonia para não haver prejuízos no seu funcionamento, também a Igreja deveria unir os fiéis e expurgar ou expulsar os contrários. Pode parecer contraditório, mas o livre-arbítrio, neste caso, deve servir à subordinação voluntária do sujeito à conformidade do bem-estar humano.

A prudência em Aristóteles seria uma virtude intelectual que possibilitaria a orientação das ações humanas, tendo em vista o seu teor incerto e, na maioria das vezes, imprevisível. Tomás de Aquino, por sua vez, afirma que a prudência é parte de um modelo de conduta inteiramente afinado à vontade da Providência. Este modelo reproduz os desígnios divinos ainda que pautado nas limitações humanas, tratando-se, portanto, de um atributo que se situa entre a virtude intelectual e a virtude moral. ${ }^{4}$

Prosseguindo com nossa análise, se seguirmos os passos de Hélio Alves, as atitudes de Gama não seriam pautadas na virtude ético-política da prudência. Para ele, há um desajuste entre o retrato do protagonista pintado n'Os lusíadas e as descrições do mesmo presentes nas crônicas históricas, que consideram Gama um homem prudente e sábio. No caso da epopeia, estariam ausentes os qualificativos necessários para a configuração de um herói que, pelo contrário, chega mesmo a reproduzir certas ações viciosas. Dentre as imprudências que Hélio Alves encontra espalhadas pelo poema, destaca-se a falta de tato diplomático do capitão, descuidado a ponto de maldizer os turcos (com quem os povos de Moçambique mantinham relações amigáveis) e contradizer a crença do xeque. Assim, o ódio dos mouros seria devido não

\footnotetext{
${ }^{3}$ A noção de kairos, entendida como tempo oportuno ou ocasião favorável, indica "o bem segundo o tempo, ou ainda, o tempo enquanto nós o consideramos bom". Ver: (AUBENQUE, 2008, p.193-229).

4 É necessário dizer que o aristotelismo, em seu início, se mostrou incompatível com a noção da verdade revelada, ou do Deuscriador, próprias do cristianismo. Tomás de Aquino não segue à risca as premissas aristotélicas, mas promove uma releitura delas, o que serve para se pensar os escritos posteriores. É provável que boa parte da doutrina de Santo Tomás de Aquino tenha vínculos, também, com o pensamento platônico, o que nos leva a rever o anacronismo que atribui a Agostinho uma veia platônica, e a Tomás de Aquino uma postura puramente aristotélica. Sugerimos a leitura de: (KOYRÉ, 1991, p.22-45).
} 
ao Cristianismo, mas à maneira como o capitão-mor se manifestou frente a eles. O poeta, portanto, teria desconstruído o caráter e a conduta do herói, esvaziados da prudência que cronistas como Fernão Lopes de Castanheda e João de Barros Ihe quiseram atribuir. Muitas de suas faltas, no entanto, acabaram sendo compensadas pela intervenção dos deuses mitológicos, como Vênus. Embora o poeta Ihe atribua qualidades grandiosas, as ações do protagonista, segundo Alves, não corresponderiam às virtudes que Camões valorizava. ${ }^{5}$

Para alegar a falta de prudência demonstrada no modo como Vasco da Gama conduziu suas ações, Hélio Alves diz que mesmo uma conduta condenável pode reforçar um éthos prudente, pela inversão. Por outras palavras, com a denúncia de um falso herói, poder-se-ia reforçar o padrão ético encomiado pelo aedo. A prudência que faltou a Gama não deixaria de reforçar uma determinada retórica prudencial.

Falar de um "falso herói" levando-se em consideração os deslizes mencionados por Alves seria, contudo, exagero. Se os deuses mitológicos intervêm para sanar as falhas do protagonista, isto decorre do papel nuclear exercido por Deus, que utiliza Gama como seu arauto. Camões incorporou o sentido providencial da história não apenas para justificar o uso do maquinário mitológico, mas também para retratar os limites do homem português. A conduta de Gama não é impecável, mas sua subserviência à vontade providencial, refletida na virtude da caridade, assegura seu amparo e o posterior sucesso da empresa. Isto porque ele é um dentre os vários instrumentos que Deus mobiliza para obrar em Seu nome.

\section{Considerações finais}

As ações de Gama, vivenciadas a bordo do navio ou em terras orientais, devem ser compreendidas a partir de uma concepção providencialista da história portuguesa. No limite, é este providencialismo que ilumina sua experiência e seu desempenho heroico. A sua persona só pode ser entendida sob uma perspectiva católica contrarreformada, pois Camões emulou a filosofia aristotélico-tomista, edificando uma conduta afinada à reta razão, à moderação dos afetos, de modo que não há nele o ímpeto guerreiro de um Aquiles, mas a humildade própria de um agente da Providência que, simultaneamente, atua como braço da realeza. Não é por outro motivo que, ao final do poema, os portugueses se unem às ninfas para selar a vitória sobre os mares, tornada possível graças ao amparo divino, figurado poeticamente por meio de deidades romanas. Afirma-se, por um lado, a impossibilidade de contemplar a Causa Primeira, emanação de pura luz que impossibilita a visão, e apregoa-se a necessidade de evitar os vícios e pecados, que levam à cegueira por eliminar a razão e priorizar os apetites, as paixões. Não se trata de falta de heroísmo, mas da presença de um herói "mediano", pois no ponto médio encontrar-se-ia, de fato, a orientação da ação virtuosa. O sublime, outrora presente na conduta magnífica de um guerreiro semidivino ansioso por fama perene, sob o monoteísmo que moveu Abraão e, depois, Gama, torna-se atributo exclusivo da divindade.

${ }^{5}$ Ver: ALVES, 2001, p. 449-511. 


\section{Referências bibliográficas}

ALIGHIERI, Dante. A Divina Comédia. Introdução, tradução e notas de Vasco Graça Moura. São Paulo: Editora Landmark, 2005.

ALVES, Hélio J. S. Camões, Corte-Real e o sistema da epopeia quinhentista. Coimbra: Centro Interuniversitário de Estudos Camonianos, 2001.

ARISTÓTELES. Ética a Nicômaco. Tradução do grego de António de Castro Caeiro. São Paulo: Atlas, 2009.

AUBENQUE, Pierre. A prudência em Aristóteles. Tradução de Marisa Lopes. São Paulo: Discurso Editorial, Paulus, 2008.

BOTTÉRO, Jean. No começo eram os deuses. Tradução de Marcelo Jacques de Morais. Rio de Janeiro: Civilização Brasileira, 2011.

CAMÕES, L. Os Lusíadas. Porto Alegre: L\&PM, 2008.

CORTE-REAL, Jerónimo. Naufrágio de lastimoso sucesso de perdição de Manuel de Sousa de Sepúlveda, e Dona Lianor de Sá sua mulher e filhos, vindo da Índia para este reino na nau chamada o galeão grande $S$. João que se perdeu no cabo de boa Esperança, na terra do Natal. Lisboa: oficina de Simão Lopes, 1594.

HANSEN, João Adolfo. A máquina do mundo. In: NOVAES, Adauto (org.). Poetas que pensaram o mundo. São Paulo: Companhia das Letras, 2005.

HANSEN, João Adolfo. Notas de leitura. In: ALIGHIERI, Dante. Divina Comédia. Tradução e notas de João Trentino Ziller. Cotia, SP: Ateliê Editorial; Campinas, SP: Editora da UNICAMP, 2010.

KOYRÉ, Alexandre. Aristotelismo e Platonismo na Filosofia da Idade Média. In: Estudos de História do Pensamento Científico. Tradução de Márcio Ramalho. Rio de Janeiro: Forense Universitária, 1991, p. 22-45.

LUZ, Guilherme Amaral. Produção da concórdia: a poética do poder na América portuguesa (sécs. XVI-XVIII). In: Varia Historia, Belo Horizonte: UFMG, v. 23, n. 38, 2007, p. 558-560.

RÖMER, Thomas. A origem de Javé: o Deus de Israel e seu nome. Tradução de Margarida Maria Cichelli Oliva. São Paulo: Paulus, 2017.

SARAIVA, António José. Luís de Camões: estudo e antologia. Lisboa: Livraria Bertrand, 1980.

SKA, Jean-Louis. Abraão e seus hóspedes - o patriarca e aqueles que creem no Deus único. Tradução de Odila Aparecida de Queiroz. São Paulo: Edições Loyola, 2009.

TASSO, T. Jerusalém Libertada. Tradução de José Ramos Coelho. Organização, introdução e noras de Marco Lucchesi. Rio de Janeiro: Topbooks, 1998.

TEIXEIRA, B. Prosopopéia. Rio de Janeiro: Instituto Nacional do Livro, 1972.

TEIXEIRA, Felipe Charbel. Timoneiros: retórica, prudência e história em Maquiavel e Guicciardini. Tese de doutoramento. Rio de Janeiro: Pontifícia Universidade Católica do Rio de Janeiro, 2008.

TOMÁS DE AQUINO, Santo. A prudência: a virtude da decisão certa. Tradução, introdução e notas de Jean Lauand. São Paulo: Martins Fontes, 2005. 